\title{
How Personality and Policy Predict Pandemic Behavior: Understanding Sheltering-in- Place in 55 Countries at the Onset of COVID-19
}

\author{
Friedrich M. Götz1,*, Andrés Gvirtz1, Adam D. Galinsky2 \& Jon M. Jachimowicz3
}

1 Department of Psychology, University of Cambridge, UK

${ }_{2}$ Columbia Business School, Columbia University, NY, USA

3 Harvard Business School, Harvard University, MA, USA

* To whom correspondence should be addressed: fmg33@cam.ac.uk

Methods and Materials can be accessed at the project website: https://osf.io/3sn2k/. Data and code to reproduce the results of the current research can be accessed here: https://osf.io/tuenj/

Accepted version, 19-Aug-2020 (in press, American Psychologist).

This preprint may differ slightly from the final, copy-edited version of record.

(C)American Psychological Association, 2020. This paper is not the copy of record and may not exactly replicate the authoritative document published in the APA journal. Please do not copy or cite without author's permission. The final article is available, upon publication, at:

10.1037/amp0000740 


\begin{abstract}
The spread of COVID-19 within any given country or community at the onset of the pandemic depended in part on the sheltering-in-place rate of its citizens. The pandemic led us to revisit one of psychology's most fundamental and most basic questions in a high-stakes context: What determines human behavior? Adopting a Lewinian interactionist lens, we investigate the independent and joint effects of macro-level government policies and micro-level psychological factors - i.e., personality — on whether individuals sheltered-in-place. We analyzed data collected in late March and early April 2020 from 101,005 participants in 55 countries, a time period that coincided with the early and accelerating stage of the COVID-19 pandemic. This time period also contained substantial variation in the stringency of governmental policy towards shelteringin-place, both between countries and within each country over time. Analyses revealed that personality and the stringency of governmental policies independently predicted sheltering-inplace rates. Policy stringency was positively related to sheltering-in-place. For the personality dimensions, openness, conscientiousness, agreeableness, and neuroticism all predicted higher rates of sheltering-in-place, whereas extraversion was negatively related to staying at home. In addition, two personality traits—openness to experience and neuroticism—interacted with governmental policy to predict whether individuals sheltered-in-place; openness and neuroticism each had weaker effects on sheltering-in-place as governmental policies became stricter. Theoretically, the findings demonstrate that individual differences predict behavior (i.e., sheltering-in-place) even when governments take strong action targeting that behavior. Practically, they suggest that even if governments lift their shelter-in-place restrictions, some individuals will shelter-in-place less than others.
\end{abstract}

Keywords: shelter-in-place, personality, government, interactionism, COVID-19 


\section{Public Significance Statement}

To curb the spread of current and recurrent waves of COVID-19, individuals must stay at home when the circumstances require it. In a large-scale global sample, we demonstrate how individual personality and policy stringency jointly and independently determine whether or not someone will shelter-in-place. Our findings suggest that as governments provisionally relax sheltering-inplace restrictions, some individuals will continue to engage in social distancing behaviors more than others. 
As the world wrestles with the COVID-19 pandemic, controlling the outbreak within any given country comes down, at least in part, to the behaviors of its citizens (Anderson, Heesterbeek, Klinkenberg, \& Hollingsworth, 2020). One particularly important behavior to decrease the spread of COVID-19—especially at the onset of the pandemic — is for people to stay at home, i.e., to shelter-in-place. The individual decision to shelter-in-place offers a unique research opportunity for social scientists (van Bavel et al., 2020). Indeed, understanding why humans behave the way they do is one of the oldest, most central, and most divisive questions in psychology. For decades, social psychologists have stressed the power of situational (Mischel, 1977; Ross \& Nisbett, 1991) and environmental factors (Barker, 1968; Bronfenbrenner, 1977), whereas personality psychologists have emphasized the role of stable psychological traits, such as the Big Five (Digman, 1990, John \& Srivastava, 1999; Soto \& John, 2017), in explaining behavior (Ozer \& Benet-Martínez, 2006; Soto, 2019).

Prior research suggests multiple plausible links between Big Five personality traits and sheltering-in-place. For example, one personality trait, openness to experience-which reflects individual differences in curiosity, experimentation, risk-taking, and a willingness to deviate from cultural norms (Schaller \& Murray, 2008) — might be related to sheltering-in-place in different ways. The greater curiosity of more open individuals often manifests in a less cautious attitude towards novel and unfamiliar things, implying that these individuals may be more likely to put themselves at elevated risk for contracting infectious diseases and pathogens (Schaller \& Murray, 2008; Schaller \& Park, 2011). Furthermore, open individuals display greater willingness to deviate from cultural norms, which may include norms and collective practices that have evolved to neutralize pathogen threats (e.g. normative guidelines regarding hygiene and food preparation; Fabrega, 1997; Tybur et al., 2016). On the other hand, openness to experience is 
also related to more accurate risk perceptions, which may facilitate the adoption of adequate health behaviors, such as sheltering-in-place (Trobst et al., 2000).

For other personality traits, prior literature is more conclusive about their projected relationship to sheltering-in-place. Consider that conscientiousness is associated with higher adherence to medical advice (Hill \& Roberts, 2011), fewer risky health behaviors (Raynor \& Levine, 2009; Roberts, Walton, \& Bogg, 2005; Soto, 2019), as well as greater compliance with norms, rules (Marcus \& Schuler, 2004; Roberts, Chernyshenko, Stark, \& Goldberg, 2005) and civic duties (Schoen \& Steinbrecher, 2013). More agreeable individuals tend to follow social norms (Roccas, Sagiv, Schwartz, \& Knafo, 2002) and are less likely to engage in risky health behaviors (Raynor \& Levine, 2009; Strickhouser, Zell, \& Krizan, 2017). Meanwhile, although neuroticism is generally associated with poor physical and mental health (Charles, Gatz, Kato, \& Pedersen, 2008; Lahey, 2009), people who score higher on neuroticism tend to be more fearful of danger and disease (Duncan, Schaller, \& Park, 2009; Faulkner et al., 2004), and have been shown to engage in more thorough hygienic and germ avoidance behavior (Aunger et al., 2016; Duncan et al., 2009). In contrast, extraversion is associated with more risky health behaviors (Raynor \& Levine, 2009; Strickhouser et al., 2017) and decreased germ aversion (Duncan et al., 2009).

In summary, previous research provides various insights into how different personality traits might be related to sheltering-in-place. However, given the historical uniqueness and unprecedented scale of the COVID-19 pandemic, it is unclear if the same psychological processes identified in previous research (and briefly reviewed above) also apply to the current situation. 
At the same time, one might expect macro-level policies to override micro-level individual differences in personality in predicting pandemic-related behavior. Conceptually, this idea is consistent with the strong situation hypothesis (Cooper \& Withey, 2009; Mischel, 1977). According to this perspective, in strong situations, such as during rigorously enforced nationwide lockdowns, there are clear social norms that prescribe a very limited range of appropriate behaviors. Consequently, opportunities for behavioral variability are constrained in these situations and most people will exhibit similar behaviors. As a result, individual differences in personality may matter less, or even not at all. In contrast, in weak situations, such as when governments only release non-binding recommendations designed to decrease individual mobility, there are few constraints on personal expression, and personality may thus be a more central predictor of behavior. Consider that sheltering-in-place policies enacted by many countries enjoyed widespread approval, with polls in mid- and late March finding support among 96\% of respondents in France and Germany, and $81 \%$ of respondents in the U.S. (Infratest Dimap, 2020; Kahn, 2020; Odoxa, 2020), suggesting the establishment of salient and widely accepted social behavioral norms in the general public (Hook \& Markus, 2020; Tankard \& Paluck, 2017). As a result, consequential policy decisions may create strong situations and override individual differences when predicting sheltering-in-place.

Thus, in the current research, we examine the relative and interactive influences of the Big Five personality traits with variation in governmental stringency in restrictions related to COVID-19, both between countries and within countries over time. Our approach allows us to explore how micro-level psychological processes and macro-level policies independently and jointly shape sheltering-in-place during the onset of the global COVID-19 pandemic. 
Our dataset consisted of 101,005 participants from 55 countries with 200 or more participants collected in late March to early April 2020 (see Fetzer et al., 2020). As of March $20 \mathrm{th}$ - the date data collection began $-47 \%$ of the countries with more than 1,000 confirmed cases had workplace closures, and $39 \%$ had imposed some form of restriction to internal mobility (Dong, Du \& Gardner, 2020). Two weeks later, on April 5th- the date data collection ended — various forms of workplace closures and restrictions to internal mobility had been adopted in over $85 \%$ of the countries with more than 1,000 confirmed cases (Hale, Petherick, Phillips, \& Webster, 2020). The timeframe of our data collection thus captures large variations in policy stringency, offering a unique opportunity to disentangle the role of personality versus structural forces in the prediction of consequential real-world behavior in a large-scale field study during the global COVID-19 pandemic.

\section{Methods}

Participants. The data for this research comes from the "Measuring Worldwide COVID19 Attitudes and Beliefs" project (Fetzer et al., 2020; materials and measures are available at the https://osf.io/tuenj/) which was conducted as a collaborative group effort by 14 researchers, including the first and fourth author of the current project.1 The project encompassed a global survey that primarily sought to assess participants' own behaviors and perceptions of others' behaviors during the COVID-19 crisis as the pandemic unfolded. Participants also provided basic sociodemographic information and completed a measure of personality. The online survey was available in 69 languages, which had been back-translated and cross-verified by volunteering native speakers. 
Individuals were invited to participate using a variety of sources, including national media and agencies, social media platforms, academic and educational networks, NGOs, and professional organizations. Between March 20th and April 5th 2020, more than 110,000 individuals from 175 countries participated. In this report, we present the results from 55 countries with 200 or more participants, comprising a sample of 101,005 individuals (see Table $\mathrm{S} 1$ in the online supplement for an overview of participants by country). The average age of participants was 39.17 years $(S D=13.0), 57.2 \%$ identified as female, and on average, had completed 16.4 years of education $(S D=4.7)$.

\section{Measures.}

Independent Variable: Big-5 Personality. Personality was assessed through the Ten Item Personality Inventory (TIPI; Gosling, Rentfrow, \& Swann, 2003), a widely established, parsimonious short measure of the Five-Factor Model of personality (Digman, 1990; John \& Srivastava, 1999; McCrae \& Costa, 2010; Soto \& John, 2017). The TIPI has been translated and validated in dozens of languages (e.g., Chiorri, Bracco; Piccinno, Modafferi, \& Battini, 2014; Lu, Liu, Liao, \& Wang, 2020; Muck, Hell, \& Gosling, 2007; Oshio, Abe, \& Cutrone, 2012), which made it particularly useful for this global project. Each Big-5 trait was assessed through two items on a 7-point Likert scale ( $1=$ disagree strongly, $7=$ agree strongly).

Independent Variable: Stringency of Governmental Policy. To assess national policy stringency, we used the COVID-19 Government Response Stringency Index (Hale et al., 2020), which considers seven policy measures (i.e., school closing, workplace closing, cancellation of public events, suspension of public transport, implementation of public information campaign, restrictions on internal movement and international travel controls) and assigns stringency scores to each policy measure as a function of whether their implementation is absent, targeted or 
general. The seven scores are averaged to create a composite COVID-19 Government Response Stringency Index, which ranges from 0 to 100.

Dependent Variable: Shelter-in-Place. Participants were asked to indicate the extent to which they had stayed at home during the past week on a scale from 0 to 100 (anchors: $0=$ does not apply at all, $100=$ applies very much).

Control Variables. As part of the online survey, we also assessed various sociodemographic variables that were used as control variables in our analysis. Specifically, participants reported their age, gender, how many years of education they had completed, their income (divided into within-country quintiles, with $1=$ lowest, $5=$ highest), and their health status $(1=$ poor, $2=$ fair, $3=$ good, and $4=$ excellent $) .2$ To control for the number of confirmed cases of COVID-19 infections and deaths, we obtained chronological data for each country from the John Hopkins Mapping 2019-nCoV project (Dong, et al., 2020), which we logged given their skewed distribution, adjusted according to national population, and controlled for at $t$-1, i.e., from the day before participants completed the survey. Finally, given that subjective beliefs about true caseloads may differ from actual reported numbers, we also asked participants to estimate how many residents of their country were infected at the time of participation, and forecast how many would be infected in a month's time.

Analytical Strategy and Model Specifications. To address our research questions, we fitted a series of increasingly conservative multilevel models examining main and interaction effects of Big Five personality traits and policy stringency on sheltering-in-place. The benchmark model (Model 1) considered only control variables (i.e., individual age, gender,

2 Income was not reported for 5,684 (5.63\%) participants. We used multiple imputation using multivariate normal distribution (MVN) to impute the missing variables based on participants education, gender, age and country of residence with Markov Chain Monte Carlo (MCMC) procedure and 10 imputations. All results are similar when we exclude these participants. 
education, income, and health status as well as number of confirmed cases, confirmed deaths in each respective country and perceived current and future severity). Model 2 added the main effects of the Big-5 personality traits and governmental stringency. Model 3 further added the interaction terms between stringency and each of the Big-5 traits.3 We grand-mean-centered all non-binary variables and included random factors for day and country in all models, which allowed us to account for potential unobserved heterogeneity. We applied Dunn-Bonferronicorrections to account for the increased likelihood of type 1 error due to multiple hypothesis testing (Shaffer, 1995). Furthermore, we adopted recent guidelines for conservative significance testing of novel effects, which we deemed particularly important in the context of a global pandemic (Enserink \& Kupferschmidt, 2020; Lewis, 2020). While there are different positions on this topic (Lakens et al., 2018), we followed Benjamin and colleagues (2018) by setting the significance level for our focal analyses to $p=.005$ (see also IJzerman et al., 2020). Data and code to reproduce the analyses of the current research are available on the Open Science Framework (osf.io/tuenj/?view_only=c329b3de0886403eaf1922e1cb8ed6a8).

\section{Results}

Table 1 summarizes the results from our multilevel analyses. Bivariate correlations are displayed in Table S2 in the online supplement. Our analyses reveal that both governmental stringency and personality independently predicted sheltering-in-place rates. Providing support for the effectiveness of the governmental policies designed to encourage sheltering-in-place, governmental stringency was positively related to respondents' propensity to shelter-in-place $(b$

3 To further test the adequacy of our multilevel models, we employed Cook's distance to screen for multivariate outliers. Due to the unwieldly size of the sample, we calculated Cook's distance across two randomly drawn samples of 10,000 participants each; the highest single value (0.007) was far below the recommended threshold of 0.5 , indicating that only minimal bias due to multivariate outliers was present (see Figure S1 in the online supplement). We also checked variance inflation factors (VIFs), accounting for the multilevel structure of our data. Most values were close to 1 , with the highest VIF being 1.97, suggesting that variance inflation did not pose a significant threat to the validity of our findings. 
$=.094, S E=.009, p<.001)$. Our analyses also indicate that openness $(b=.040, S E=.003, p<$

$.001)$, conscientiousness $(b=.013, S E=.003, p<.001)$, agreeableness $(b=.014, S E=.003, p<$

$.001)$, and neuroticism $(b=.019, S E=.003, p<.001)$ were positively related to sheltering-in-

place. In contrast, extraversion was negatively related to sheltering-in-place $(b=-.025, S E=$

$.003, p<.001) .4$

\section{Table 1}

Sheltering-in-Place Predicted by Big-5 Personality and Governmental Stringency

\begin{tabular}{|c|c|c|c|}
\hline & Model 1 & Model 2 & Model 3 \\
\hline \multirow[t]{2}{*}{ Constant } & .112 & .071 & .071 \\
\hline & $(.065)$ & $(.057)$ & $(.057)$ \\
\hline \multirow[t]{2}{*}{ Age } & $-.033 * * *$ & $-.033 * * *$ & $-.033 * * *$ \\
\hline & $(.003)$ & $(.003)$ & $(.003)$ \\
\hline \multirow[t]{2}{*}{ Female } & $.045^{* * *}$ & $.036^{* * *}$ & $.036^{* * *}$ \\
\hline & $(.006)$ & $(.006)$ & $(.006)$ \\
\hline \multirow[t]{2}{*}{ Education } & $.036 * * *$ & $.035^{* * *}$ & $.035^{* * *}$ \\
\hline & $(.003)$ & $(.003)$ & $(.003)$ \\
\hline \multirow[t]{2}{*}{ Health } & $-.015 * * *$ & $-.015 * * *$ & $-.015 * * *$ \\
\hline & $(.003)$ & $(.003)$ & $(.003)$ \\
\hline \multirow[t]{2}{*}{ Income (binned) } & -.004 & -.002 & -.002 \\
\hline & $(.003)$ & $(.003)$ & $(.003)$ \\
\hline \multirow[t]{2}{*}{ Logged Confirmed Cases $(t-1)$} & $-.129 * * *$ & $-.114 * * *$ & $-.115^{* * *}$ \\
\hline & $(.012)$ & $(.012)$ & $(.012)$ \\
\hline \multirow[t]{2}{*}{ Logged Confirmed Deaths $(t-1)$} & .026 & .025 & .026 \\
\hline & $(.009)$ & $(.009)$ & $(.009)$ \\
\hline \multirow[t]{2}{*}{ Estimated Infections Now } & -.008 & -.008 & -.008 \\
\hline & $(.003)$ & $(.003)$ & $(.003)$ \\
\hline \multirow[t]{2}{*}{ Estimated Infections in One Month } & $.013^{* *}$ & $.013^{* *}$ & $.012 * *$ \\
\hline & $(.003)$ & $(.003)$ & $(.003)$ \\
\hline \multirow[t]{2}{*}{ Stringency Index } & & $.095 * * *$ & $.094 * * *$ \\
\hline & & $(.009)$ & $(.009)$ \\
\hline \multirow[t]{2}{*}{ Openness } & & $.040 * * *$ & $.040^{* * *}$ \\
\hline & & $(.003)$ & $(.003)$ \\
\hline \multirow[t]{2}{*}{ Conscientiousness } & & $.013 * * *$ & $.013^{* * *}$ \\
\hline & & $(.003)$ & $(.003)$ \\
\hline \multirow[t]{2}{*}{ Extraversion } & & $-.025 * * *$ & $-.025 * * *$ \\
\hline & & $(.003)$ & $(.003)$ \\
\hline
\end{tabular}

4 Of note, Akaike Information Criterion and Bayesian Information Criterion indicated that adding personality and stringency as predictors in Model 2 substantially improved model fit. In contrast, including the interaction terms between each Big Five trait and stringency in Model 3 did not yield any incremental gains in model information. Thus, from a statistical perspective, Model 2, and its focus on independent effects, offered the more parsimonious solution. However, given our research interest in both the independent and joint effects of personality and policy stringency on sheltering in place, we included Model 3 which contained the interaction effect between all personality traits and governmental stringency in our results. 


\begin{tabular}{|c|c|c|c|}
\hline Agreeableness & & $\begin{array}{c}.014 * * * \\
(.003)\end{array}$ & $\begin{array}{c}.014 * * * \\
(.003)\end{array}$ \\
\hline Neuroticism & & $\begin{array}{c}.019 * * * \\
(.003)\end{array}$ & $\begin{array}{c}.019 * * * \\
(.003)\end{array}$ \\
\hline Openness $x$ Stringency Index & & & $\begin{array}{c}-.013 * * * \\
(.003)\end{array}$ \\
\hline Conscientiousness $x$ Stringency Index & & & $\begin{array}{l}-.002 \\
(.003)\end{array}$ \\
\hline Extraversion $x$ Stringency Index & & & $\begin{array}{c}.004 \\
(.003)\end{array}$ \\
\hline Agreeableness $x$ Stringency Index & & & $\begin{array}{c}.008 \\
(.003)\end{array}$ \\
\hline Neuroticism $x$ Stringency Index & & & $\begin{array}{c}-.016^{* * * *} \\
(.003)\end{array}$ \\
\hline Observations & 101,005 & 101,005 & 101,005 \\
\hline Akaike Inf. Crit. & $274,676.438$ & $274,399.199$ & $274,409.445$ \\
\hline Bayesian Inf. Crit. & $274,800.236$ & $274,580.134$ & $274,637.995$ \\
\hline
\end{tabular}

Note. $P$-values are Dunn-Bonferroni corrected. ${ }^{*} p<.005 ;{ }^{* *} p<.001 ; * * * p<.0001$ (following Benjamin et al., 2018).

Our analyses also revealed statistically significant interaction effects between stringency and openness to experience $(b=-.013, S E=.003, p<.001)$ as well as neuroticism $(b=-.016, S E$ $=.003, p<.001)$ on sheltering-in-place. Simple slopes analyses showed that these two personality traits had a greater effect on sheltering-in-place when governmental stringency was lower (i.e., at $-1 S D$ of the stringency index; openness: $b=.05, S E=.001, p<.001$; neuroticism: $b=.03, S E=.001, p<.001)$ and a weaker effect on sheltering-in-place when governmental stringency was higher (i.e., at $+1 S D$ of the stringency index; openness to experience: $b=.03, S E$ $=.001, p<.001$; neuroticism: $b=.001, S E=.001, p=.49$; see Figure 1). In contrast, governmental stringency did not moderate the effects of conscientiousness $(b=-.002, S E=.003$, $p=.426)$, extraversion $(b=.004, S E=.003, p=.218)$, and agreeableness $(b=.008, S E=.003, p$ $=.013)$ on sheltering-in-place. 


\section{Figure 1}

\section{Simple Slopes Analysis of Relationship Between Openness to Experience (Panel A) and Neuroticism (Panel B) on Sheltering-in-Place by Stringency Index}

(a)

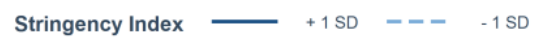

95

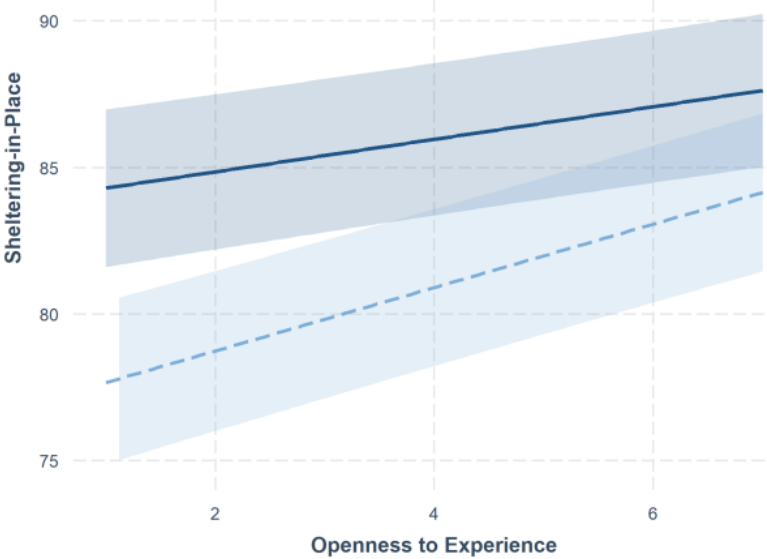

(b)

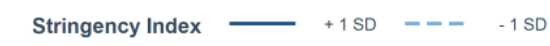

95

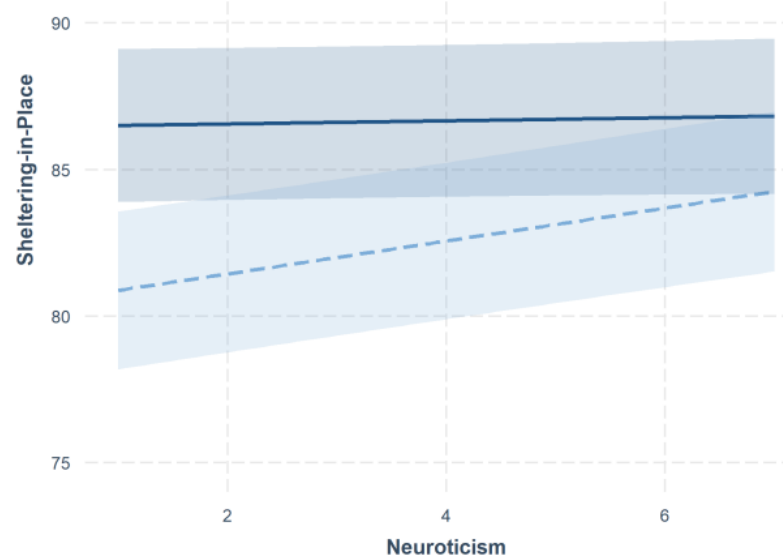

Note. Dark blue line plots the effect of personality traits at $+1 S D$ of stringency, whereas the light blue dotted line plots the effect of personality traits at $-1 S D$ of stringency. Shaded areas reflect $95 \%$ confidence intervals. The plots demonstrate that openness and neuroticism were stronger predictors when government stringency was lower.

Lastly, we conducted additional empirical checks to determine the robustness of our findings. First, to examine the extent to which our findings for sheltering-in-place may generalize to other pandemic-related behaviors, we replicated our full model for three other behaviors, i.e., hand-washing, attending social gatherings and keeping a distance of at least two meters to other people. These additional measures served as a helpful extension, but each had individual weaknesses that make them inferior to our measure of sheltering-in-place (for more details, see supplementary notes in the online supplement). Lending support to the validity of our findings, the general pattern replicated across these three behaviors (see Tables S3-S5 and supplementary notes for more details). Given the measurement limitations for each of these 
alternative behaviors, we note caution in interpreting these results, and place larger confidence in our findings on sheltering-in-place.

Second, we conducted internal replications through sample splitting. Specifically, we randomly drew 500 samples of 50,000 participants from our overall sample and reran our focal regression model (Model 3) for each of these 500 samples. Figure 2 exhibits the average effects and the interquartile ranges for our focal predictors, that is governmental policy stringency, the Big Five personality traits, and their respective interactions across these 500 iterations.

Corroborating the validity of our findings, these internal replications reproduced all effects as reported in our main model, both with respect to directionality and relative importance compared to the other predictors.

\section{Figure 2}

\section{Average Effect Sizes of Big Five Personality Traits, Governmental Policy Stringency and}

Their Interaction across 500 Random Subsamples

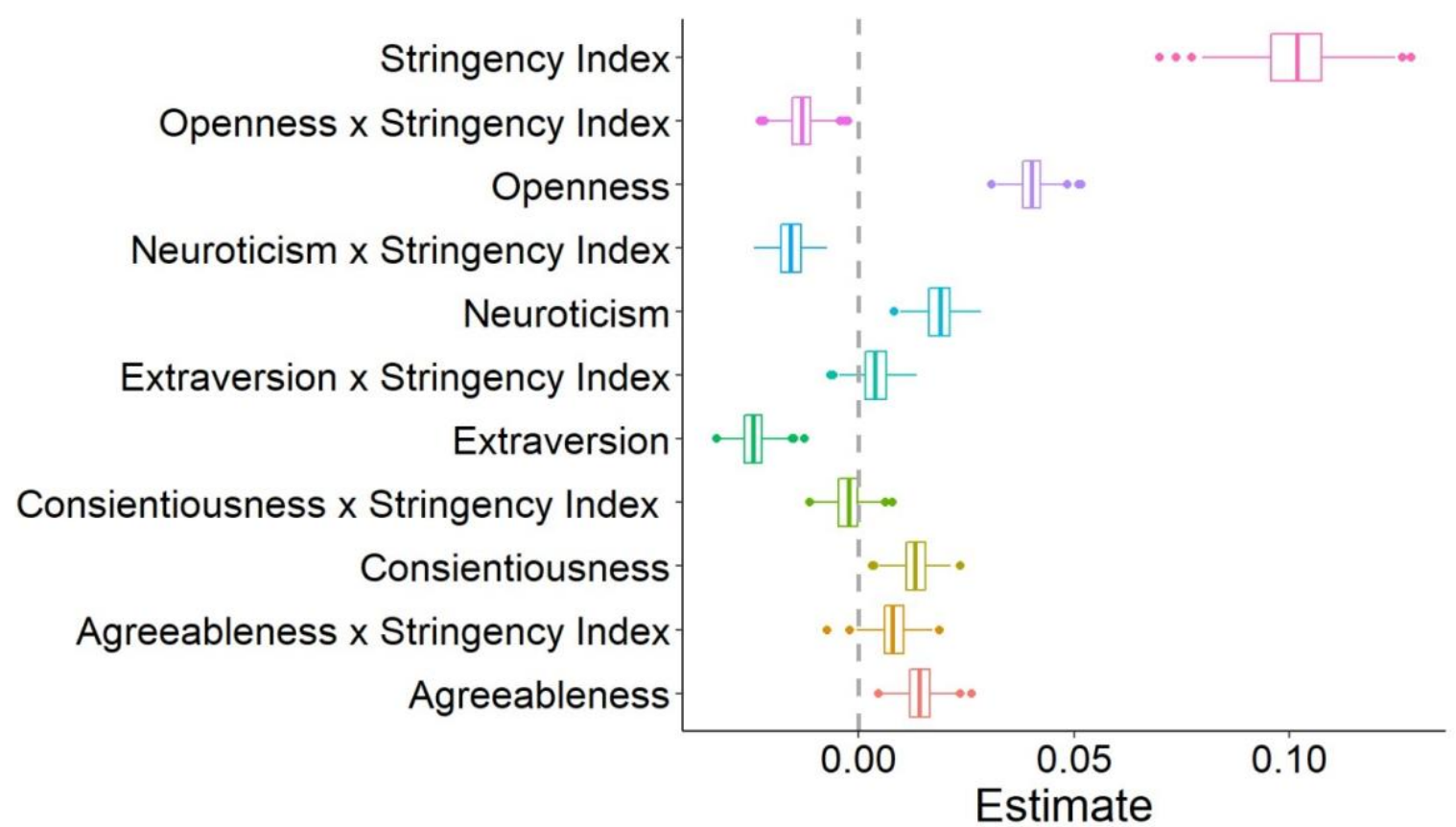

Note. Figure exhibits effect sizes across 500 iterations of 50,000 randomly drawn participants. Boxes indicate interquartile range and median (middle line). Whiskers reflect variability outside the upper and lower quartiles. Outliers are plotted as individual points. The gray dotted line indicates an effect size estimate of zero. 


\section{Discussion}

The current research examined the independent and joint effects of macro-level government policies and micro-level psychological factors - i.e., personality — on whether individuals sheltered-in-place during the early, accelerating stage of the global COVID-19 pandemic. Based on survey data we collected between late March and early April 2020 — a time period that captured heterogeneous changes in the stringency of government policies-we find that governmental stringency, as well as individual-level openness to experience, conscientiousness, agreeableness and neuroticism positively predict sheltering-in-place whereas extraversion does so negatively. The reported effects were stronger for policy stringency, openness and extraversion, than they were for neuroticism, agreeableness and conscientiousness. Importantly, the effects were robust, persisting when accounting for a conservative set of alternative predictors of sheltering-in-place, including demographic and personal factors (such as age, gender, income, and health), as well as actual and perceived COVID-19 infection and death rates.5 Moreover, our analyses also include random factors for day and country, which allow us to account for potential unobserved heterogeneity and further strengthens the methodological rigor.

With regards to effect size, policy stringency $(b=.094)$ and personality-particularly openness $(b=.040)$ - predicted sheltering-in-place with similar or greater strength than age $(b=$ $-.033)$, gender $(b=.036)$, education $(b=.035)$, income $(b=-.002, n s)$, personal health $(b=.015)$

\footnotetext{
5 Our analysis also shows that men are more likely to leave their home than women, aligning with prior research that men tend to be less risk averse than women (Byrnes, Miller \& Schafer, 1999; Figner \& Weber, 2011). Moreover, we find that more health-impaired people are less likely to leave their home, presumably because they are the most vulnerable (Wu \& McGoogan, 2020) and hence have greater incentives to stay at home. Somewhat surprisingly, we found that older people were less likely to shelter-in-place, which however does align with recent research showing that while younger people overestimate their personal health risk during the COVID-19 pandemic, older people drastically underestimate their health risk (Bordalo, Coffman, Gennaioli, \& Shleifer, 2020). Lastly and intuitively, the actual severity of COVID-19 spread, as well as subjective anticipation of future spread, were negatively related to the propensity of leaving one's home.
} 
and perceived $(b=-.008, n s)$ as well as anticipated severity of COVID-19 spread $(b=.012)$, and persisted when accounting for the strongest predictor, i.e., confirmed cases per country. This being said, it should be noted that the effects were generally quite small. For example, a one standard deviation increase in openness, i.e., a difference of 1.15 points on the 7-point Likert scale that was used to measure openness, corresponded to a change of .04 standard deviations in the propensity to shelter-in-place, i.e., an increase of .94 on the 0-100 scale used to measure sheltering-in-place. However, from an applied perspective, even such comparatively small effects can have important consequences when accumulating over time and at scale (Funder \& Ozer, 2019; Matz, Gladstone, \& Stilwell, 2017). Given the worldwide scale of the COVID-19 pandemic and the contagiousness of the virus, small changes in people's probability to shelter-inplace can substantially reduce the spread of COVID-19 both within and across countries (Dehning et al., 2020; Kissler, Tedijanto, Goldstein, Grad, \& Lipsitch, 2020).

The observed effects are broadly in line with conceptual definitions of Big-5 personality traits (DeYoung, Quilty, \& Peterson, 2007; John \& Srivastava, 1999; Soto \& John, 2017) and prior research. For instance, more neurotic people are hypervigilant and experience anticipatory anxiety and threat sensitivity (Barlow, Ellard, Sauer-Zavala, Bullis, \& Carl, 2014; Drabant et al., 2011), consistent with increased sheltering-in-place. Although openness has previously been associated with risky behaviors even during pandemics (Schaller \& Murray, 2008), openness is also related to accurate risk perceptions (Trobst et al., 2000), as well as universalism (ParksLeduc, Feldman, \& Bardi, 2015) and humankind identification (McFarland, Webb, \& Brown, 2012), which may lead individuals to act ahead of the curve following the COVID-19 outbreak in other countries. In addition, openness may be related to increased sheltering-in-place through its associations with political attitudes. At least in the United States, the country with the second- 
highest number of participants in our sample (see Table S1), openness is robustly linked with liberal political attitudes (Jost, 2006; McCrae, 1996). In line with this view, recent evidence shows that during the COVID-19 pandemic, liberals were disproportionately more likely to acknowledge the severity of the situation (Allcott et al., 2020; Gadarian, Goodman, \& Pepinsky, 2020), search for COVID-related information (Barrios \& Hochberg, 2020), support drastic policies (van Holm, Monaghan, Sahar, Messina, \& Suprenant, 2020), switch to e-commerce (Painter \& Qiu, 2020) and comply with social distancing guidelines (Allcott et al,. 2020; Gadarian et al., 2020; van Holm et al., 2020; Painter \& Qiu, 2020) than their conservative counterparts. Extraversion was the only negative predictor of sheltering-in-place, which is consistent with its subfactors of sociability and assertiveness as well as previous research tying this trait to various risky health behavior (Raynor \& Levine, 2009; Strickhouser et al., 2017) and decreased germ aversion (Duncan et al., 2009).

Furthermore, our analyses reveal interaction effects between policy stringency and openness to experience and neuroticism. Specifically, we found that individuals low in openness to experience and neuroticism were less likely to have sheltered-in-place in the absence of stringent government measures, and that these effects became weaker when policy stringency increased. Meanwhile no interaction effects were observed for the remaining Big Five traits, i.e. agreeableness, conscientiousness and extraversion. On the one hand, this speaks to the general power of personality which continues to drive behavior even in highly controlled situational forces and cannot be entirely overridden by stringent governmental policies. On the other hand, it is also in line with trait activation theory (Tett \& Burnett, 2003; Tett \& Guterman, 2000), suggesting that governmental stringency may have differential relevance for different personality traits. 
Although the underlying mechanisms are unclear, we offer the following tentative explanation for the observed interaction effects. Regarding the interaction between policy stringency and openness, consider that individuals scoring higher on openness are generally more willing to seek out new information and are faster to adapt to changing situations (McCrae, 1996; Obschonka, Schmitt-Rodermund, Silbereisen, Gosling, \& Potter, 2013). Moreover, as mentioned above, in the specific context of the worldwide COVID-19 pandemic, the globalmindedness associated with openness to experience (McFarland et al., 2012; Parks et al., 2015) may further lead individuals to become more aware of the virus' risk and adopt protective behaviors earlier as they follow the outbreaks in other countries. Regarding the interaction between policy stringency and neuroticism, individuals scoring high on neuroticism are highly sensitive to threats and have a lower threshold to experience anxiety (Barlow et al., 2014; Drabant et al., 2011) and act accordingly (Lahey, 2009). Consistent with these general tendencies, initial evidence suggests that neurotic people are more likely to attend to and worry about COVID-19 related information (Kroencke, Geukes, Utesch, Kuper, \& Back, 2020), thus having a greater likelihood to perceive COVID-19 as a severe threat, and may consequently change their behavior in response to relevant policies earlier than less neurotic people. Taken together, the defining characteristics of openness and neuroticism may suggest that individuals scoring higher on these traits may have started sheltering-in-place before it was mandated by governmental policy. Put differently, there appear to be good reasons to assume that openness and neuroticism may have been relevant in the very beginning of the pandemic, but decreased in importance once governmental intervention transforms the adoption of such behaviors from largely individual decisions to all-encompassing social norms (Hook \& Markus, 2020; Tankard \& Paluck, 2017). 
In contrast, there was no moderating effect for extraversion. Consider that the central facet of extraversion is sociability (Soto \& John, 2017; McCrae \& Costa, 2010), which manifests itself in heightened mobility (Ai, Liu, \& Zhao, 2019) and larger social networks (Asendorpf \& Wilpers, 1998; Pollet, Roberts, \& Dunbar 2011). Because more stringent government policies are more likely to deny extraverted people the behavioral freedom that matters so highly to them, extraverted individuals may be less likely to comply with policy interventions.

Governmental stringency may affect the subcomponents of the broader traits (Costa \& McCrae, 1995; Soto \& John, 2017) in different and potentially opposing ways, thus possibly yielding opposing facet-level effects which may cancel each other out and reduce or even suppress associations at the domain level (Rammstedt, Danner, Soto, \& John 2020). For example, on the one hand, more conscientious people are more likely to follow rules (John \& Srivastava, 1999), are more cautious and socially responsible (Roberts et al., 2005), and more considerate of other people's health (Roberts, Smith, Jackson, \& Edmonds, 2008), which may make them more likely to comply with stringent government policy. On the other hand, more conscientious people are also more industrious, dutiful and self-disciplined (McCrae \& John, 1992; Roberts et al., 2005), which may make them more likely to continue leaving their home in order to go to work (Judge, Martocchio, \& Thoresen, 1997) and follow other aspects of their routine, including exercise (Conner \& Abraham, 2001; Sutin et al., 2016). Along those lines, more agreeable people tend to be more empathetic, more compassionate, and more conformist (DeYoung et al., 2007; John \& Srivastava, 1999; Roccas et al., 2002), which may make them more likely to comply with governmental stringency and stay at home. At the same time, more agreeable people also seek more frequent interpersonal contact (McCrae \& Costa, 1989)_ although unlike extraverts, they prefer small but intimate social networks (Harari et al., 2019; 
Wilson, Harris, \& Vazire, 2015)—which may also make it more difficult for them to abide by social distancing rules.

We note several limitations of the current research. First, as it was not feasible to include in-person behavioral observations due to the large timeframe, sample size, and global scope of our research, as well as the social distancing regulations themselves (Gollwitzer, Martel, Marshall, Höhs, \& Bargh, 2020), our study used self-reports to measure sheltering-in-place. This reliance on self-report assessments may introduce distorted responses due to social desirability bias (Fisher, 1993), impression management (Lary \& Kowalski, 1990), or inaccurate memory recall (Kouchaki, \& Gino, 2016). Notwithstanding the possibility of these issues, ongoing research provides tentative evidence that self-reports at least somehwat accurately capture actual sheltering-in-place behavior (measured via objective mobility data from smartphone pedometers), both on the individual and the regional level (Gollwitzer et al., 2020). Moreover, we believe that the specific findings emerging in our analyses are highly unlikely to be driven merely through response biases. Indeed, if social desirability played a major role, one would expect more extraverted individuals, who are prone to self-presentation and self-enhancement (Barrick, \& Mount, 1996; Paulhus, Harms, Bruce, \& Lysy, 2003), to overreport their shelteringin-place. Instead, we find extraversion to be the only Big Five trait that is robustly associated with decreased sheltering-in-place. This view is also consistent with a recent study by Larsen, Petersen, and Nyrup (2020), which finds that social desirability does not seem to affect selfreported social distancing during the COVID-19 pandemic.

A second limitation of the current research is that our measure of personality was limited to a 10-item short scale. On the one hand, the TIPI has been implemented and validated in dozens of languages (e.g., Chiorri et al., 2014; Liu et al., 2020; Muck et al., 2007; Oshio et al., 
2012), which was particularly useful given the global scale of the study, and which performs reasonably well in terms of test-retest reliability, self-other convergence, factor structure, predictive validity and correlations with other Big Five instruments (Donnellan, Oswald, Baird, \& Lucas, 2006; Ehrhart et al., 2009; Gosling et al., 2003; Muck et al., 2007). On the other hand, its simplicity carries the cost of reduced content breadth, measurement precision, and the inability to examine sub-facets of personality (Credé, Harms, Niehorster, \& Gaye-Valentine, 2012). Finally, our study is restricted to the examination of direct person-situation interactions and does not speak to more complex forms, such as gene-environment correlations (Plomin, DeFries \& Loehlin, 1977) or person-environment-fit (Edwards, Cable, Williamson, Lambert, \& Shipp, 2006; Götz, Ebert, \& Rentfrow, 2018; Jokela, Bleidorn, Lamb, Gosling, \& Rentfrow, 2015).

\section{Conclusions}

Theoretically, the current research demonstrates that individual differences predict behavior (i.e., sheltering-in-place) even when governments take strong action to target that behavior. The decision to shelter-in-place during COVID-19 was predicted independently by both personality and governmental policies. This finding is consistent with a Lewinian interactionism approach (Lewin, 1951), where behavior is best understood as a function of both individual-level factors such as personality and more macro-level, situational and environmental factors (Funder, 2006; Rauthmann et al., 2014). Stringent governmental policies further decreased the influence of two personality dimensions, openness, and neuroticism, demonstrating how macro-level forces can diminish the influence of certain micro-level factors. However, these interaction effects were small and absent for the remaining three traits. 
Taken together, the results reaffirm the power of personality as a central driver of behavior, a force that is not simply eclipsed by governmental policy. One effective strategy to capitalize on the predictive power of personality might be communication tailoring. Indeed, in the age of big data, psychological targeting to increase sheltering-in-place, i.e., by framing messages to match a recipient's individual personality (Hirsh, Kang, \& Bodenhausen, 2012; Matz, Kosinski, Nave, \& Stilwell, 2017), may be both a viable and powerful approach to maximize compliance behaviors.

As of writing, many governments have started loosening their shelter-in-place restrictions whereas others were reposing stricter guidelines. Our findings suggest that as governments lift their restrictions and potentially reinstate them in case of new spikes, some individuals will shelter-in-place less than others. 


\section{References}

Ai, P., Liu, Y., \& Zhao, X. (2019). Big Five personality traits predict daily spatial behavior: Evidence from smartphone data. Personality and Individual Differences, 147, 285-291. doi:10.1016/j.paid.2019.04.027

Allcott, H., Boxell, L., Conway, J., Gentzkow, M., Thaler, M., \& Yang, D. Y. (2020). Polarization and public health: Partisan differences in social distancing during COVID19. SSRN Electronic Journal. doi:10.2139/ssrn.3570274

Anderson, R. M., Heesterbeek, H., Klinkenberg, D., \& Hollingsworth, T. D. (2020). How will country-based mitigation measures influence the course of the COVID-19 epidemic? The Lancet, 395, 931-934. doi:10.1016/S0140-6736(20)30567-5

Asendorpf, J. B., \& Wilpers, S. (1998). Personality effects on social relationships. Journal of Personality and Social Psychology, 74, 1531-1544. doi:10.1037/0022-3514.74.6.1531

Aunger, R., Greenland, K., Ploubidis, G., Schmidt, W., Oxford, J., \& Curtis, V. (2016). The determinants of reported personal and household hygiene behaviour: A multi-country study. PLoS ONE, 11, e0159551. doi:10.1371/journal.pone.0159551

Barlow, D. H., Ellard, K. K., Sauer-Zavala, S., Bullis, J. R., \& Carl, J. R. (2014). The origins of neuroticism. Perspectives on Psychological Science, 9, 481-496. doi:10.1177/1745691614544528

Barker, R. C. (1968). Ecological psychology: Concepts and methods for studying the environment of human behavior. Stanford, CA: Stanford Univ. Press.

Barrick, M. R., \& Mount, M. K. (1996). Effects of impression management and self-deception on the predictive validity of personality constructs. Journal of Applied Psychology, 81, 261-272. doi:10.1037/0021-9010.81.3.261 
Barrios, J. M., \& Hochberg, Y. V. (2020). Risk perception through the lens of politics in the time of the COVID-19 Pandemic. SSRN Electronic Journal. doi:10.2139/ssrn.3568766

Benjamin, D. J., Berger, J. O., Johannesson, M., Nosek, B. A., Wagenmakers, E.-J., Berk, R., . . . Johnson, V. E. (2018). Redefine statistical significance. Nature Human Behaviour, 2, 610. doi:10.1038/s41562-017-0189-Z

Bordalo, P., Coffman, K., Gennaioli, N., \& Shleifer, A. (2020). Older people are less pessimistic about the health risks of Covid-19. doi:10.3386/w27494

Bronfenbrenner, U. (1977). Toward an experimental ecology of human development. American Psychologist, 32, 513-531. doi:10.1037/0003-066x.32.7.513

Byrnes, J. P., Miller, D. C., \& Schafer, W. D. (1999). Gender differences in risk taking: A metaanalysis. Psychological Bulletin, 125(3), 367-383. doi:10.1037/0033-2909.125.3.367

Charles, S. T., Gatz, M., Kato, K., \& Pedersen, N. L. (2008). Physical health 25 years later: The predictive ability of neuroticism. Health Psychology, 27, 369-378. doi:10.1037/02786133.27 .3 .369

Chiorri, C., Bracco, F., Piccinno, T., Modafferi, C., \& Battini, V. (2015). Psychometric properties of a revised version of the ten item personality inventory. European Journal of Psychological Assessment, 31, 109-119. doi:10.1027/1015-5759/a000215

Cooper, W. H., \& Withey, M. J. (2009). The strong situation hypothesis. Personality and Social Psychology Review, 13, 62-72. doi:10.1177/1088868308329378

Costa, P. T., Jr., \& McCrae, R. R. (1995). Domains and facets: Hierarchical personality assessment using the revised NEO personality inventory. Journal of Personality Assessment, 64, 21-50. doi:10.1207/s15327752jpa6401_2 
Credé, M., Harms, P., Niehorster, S., \& Gaye-Valentine, A. (2012). An evaluation of the consequences of using short measures of the Big Five personality traits. Journal of Personality and Social Psychology, 102, 874-888. doi:10.1037/a0027403

Dehning, J., Zierenberg, J., Spitzner, F. P., Wibral, M., Neto, J. P., Wilczek, M., \& Priesemann, V. (2020). Inferring change points in the spread of COVID-19 reveals the effectiveness of interventions. Science, 369, eabb9789. doi:10.1126/science.abb9789

DeYoung, C. G., Quilty, L. C., \& Peterson, J. B. (2007). Between facets and domains: 10 aspects of the Big Five. Journal of Personality and Social Psychology, 93, 880-896. doi:10.1037/0022-3514.93.5.880

Digman, J. M. (1990). Personality structure: Emergence of the Five-Factor Model. Annual Review of Psychology, 41, 417-440. doi:10.1146/annurev.ps.41.020190.002221

Dong, E., Du, H., \& Gardner, L. (2020). An interactive web-based dashboard to track COVID-19 in real time. The Lancet Infectious Diseases, 20, 533-534. doi:10.1016/s14733099(20)30120-1

Donnellan, M. B., Oswald, F. L., Baird, B. M., \& Lucas, R. E. (2006). The Mini-IPIP Scales: Tiny-yet-effective measures of the Big Five Factors of Personality. Psychological Assessment, 18, 192-203. doi:10.1037/1040-3590.18.2.192

Drabant, E. M., Kuo, J. R., Ramel, W., Blechert, J., Edge, M. D., Cooper, J. R., Goldin, P. R., Hariri, A. R., \& Gross, J. J. (2011). Experiential, autonomic, and neural responses during threat anticipation vary as a function of threat intensity and neuroticism. NeuroImage, 55(1), 401-410. doi:10.1016/j.neuroimage.2010.11.040 
Duncan, L. A., Schaller, M., \& Park, J. H. (2009). Perceived vulnerability to disease: Development and validation of a 15-item self-report instrument. Personality and Individual Differences, 47, 541-546. doi:10.1016/j.paid.2009.05.001

Edwards, J. R., Cable, D. M., Williamson, I. O., Lambert, L. S., \& Shipp, A. J. (2006). The phenomenology of fit: Linking the person and environment to the subjective experience of person-environment fit. Journal of Applied Psychology, 91, 802-827. doi:10.1037/0021-9010.91.4.802

Ehrhart, M. G., Ehrhart, K. H., Roesch, S. C., Chung-Herrera, B. G., Nadler, K., \& Bradshaw, K. (2009). Testing the latent factor structure and construct validity of the Ten-Item Personality Inventory. Personality and Individual Differences, 47, 900-905. doi:10.1016/j.paid.2009.07.012

Enserink, M., \& Kupferschmidt, K. (2020). With COVID-19, modeling takes on life and death importance. Science, 367, 1414.2-1415. doi:10.1126/science.367.6485.1414-b

Fabrega, H. (1997). Earliest phases in the evolution of sickness and healing. Medical Anthropology Quarterly, 11, 26-55. doi:10.1525/maq.1997.11.1.26

Faulkner, J., Schaller, M., Park, J. H., \& Duncan, L. A. (2004). Evolved disease-avoidance mechanisms and contemporary xenophobic attitudes. Group Processes \& Intergroup Relations, 7, 333-353. doi:10.1177/1368430204046142

Fetzer, T. R., Witte, M., Hensel, L., Jachimowicz, J., Haushofer, J., Ivchenko, A., Caria, S., Reutskaja, E., Roth, C. P., Fiorin, S., Gómez, M., Kraft-Todd, G., Götz, F. M., \& Yoeli, E. (2020). Global behaviors and perceptions at the onset of the COVID-19 pandemic (No. 27082; NBER Working Paper). doi:10.3386/w27082 
Figner, B., \& Weber, E. U. (2011). Who takes risks when and why? Current Directions in Psychological Science, 20, 211-216. doi:10.1177/0963721411415790

Fisher, R. J. (1993). Social desirability bias and the validity of indirect questioning. Journal of Consumer Research, 20, 303-315. doi:10.1086/209351

Funder, D. C. (2006). Towards a resolution of the personality triad: Persons, situations, and behaviors. Journal of Research in Personality, 40, 21-34. doi:10.1016/j.jrp.2005.08.003

Funder, D. C., \& Ozer, D. J. (2019). Evaluating effect size in psychological research: Sense and nonsense. Advances in Methods and Practices in Psychological Science, 2, 156-168. doi:10.1177/2515245919847202

Gadarian, S. K., Goodman, S. W., \& Pepinsky, T. B. (2020). Partisanship, health behavior, and policy attitudes in the early stages of the COVID-19 pandemic. SSRN Electronic Journal. doi:10.2139/ssrn.3562796

Gollwitzer, A., Martel, C., Marshall, J., Höhs, J. M., \& Bargh, J. A. (2020). Connecting selfreported social distancing to real-world behavior at the individual and U.S. state level. doi:10.31234/osf.io/kvnwp

Gosling, S. D., Rentfrow, P. J., \& Swann, W. B. (2003). A very brief measure of the Big-Five personality domains. Journal of Research in Personality, 37, 504-528. doi:10.1016/s0092-6566(03)00046-1

Götz, F. M., Ebert, T., \& Rentfrow, P. J. (2018). Regional cultures and the psychological geography of Switzerland: Person-environment-fit in personality predicts subjective wellbeing. Frontiers in Psychology, 9. doi:10.3389/fpsyg.2018.00517 
Götz, F. M., Gvirtz, A., Jachimowicz, J., \& Galinsky, A. (2020). How personality and policy predict pandemic behavior: Understanding sheltering-in-place in 55 countries at the onset of Covid-19. Retrieved from osf.io/tuenj

Hale, T., Petherick, A., Phillips, M., \& Webster, S. (2020). Variation in government responses to COVID-19. Blavatnik School of Government Working Paper Series, University of Oxford. Retrieved from https://www.bsg.ox.ac.uk/sites/default/files/2020-04/BSG-WP2020-031-v4.0_0.pdf

Harari, G. M., Müller, S. R., Stachl, C., Wang, R., Wang, W., Bühner, M., ... Gosling, S. D. (2019). Sensing sociability: Individual differences in young adults' conversation, calling, texting, and app use behaviors in daily life. Journal of Personality and Social Psychology. doi:10.1037/pspp0000245

Hill, P. L., \& Roberts, B. W. (2011). The role of adherence in the relationship between conscientiousness and perceived health. Health Psychology, 30, 797-804. doi: $10.1037 / \mathrm{a} 0023860$

Hirsh, J. B., Kang, S. K., \& Bodenhausen, G. V. (2012). Personalized persuasion: Tailoring persuasive appeals to recipients' personality traits. Psychological Science, 23, 578-581. doi:10.1177/0956797611436349

Hook, C. J., \& Rose Markus, H. (2020). Health in the United States: Are appeals to choice and personal responsibility making americans sick? Perspectives on Psychological Science, 15, 643-664. doi:10.1177/1745691619896252

IJzerman, H., Lewis, N. A., Jr., Weinstein, N., DeBruine, L. M., Ritchie, S. J., Vazire, S., ... Przybylski, A. K. (2020). Psychological science is not yet a crisis-ready discipline. doi:10.31234/osf.io/whds4 
Infratest Dimap. (2020). ARD-DeutschlandTREND. Retrieved from: https://www.infratestdimap.de/umfragen-analysen/bundesweit/ard-deutschlandtrend/2020/maerz-extra/

John, O. P., \& Srivastava, S. (1999). The Big-Five trait taxonomy: History, measurement, and theoretical perspectives. In L. A. P. \& O. P. John (Ed.), Handbook of personality: Theory and research (2nd ed., pp. 102-138). New York, NY: Guilford Press.

Jokela, M., Bleidorn, W., Lamb, M. E., Gosling, S. D., \& Rentfrow, P. J. (2015). Geographically varying associations between personality and life satisfaction in the London metropolitan area. Proceedings of the National Academy of Sciences of the United States of America, 112, 725-730. https://doi.org/10.1073/pnas.1415800112

Jost, J. T. (2006). The end of the end of ideology. American Psychologist, 61, 651-670. doi:10.1037/0003-066x.61.7.651

Judge, T. A., Martocchio, J. J., \& Thoresen, C. J. (1997). Five-factor model of personality and employee absence. Journal of Applied Psychology, 82, 745-755. doi:10.1037/00219010.82 .5 .745

Kahn, C. (2020). Bipartisan majority of Americans reject Trump idea to reopen by Easter: Reuters/Ipsos poll. Retrieved from: https://www.reuters.com/article/us-healthcoronavirus-poll/bipartisan-majority-of-americans-reject-trump-idea-to-reopen-by-easterreuters-ipsos-poll-idUSKBN21E3FQ

Kissler, S. M., Tedijanto, C., Goldstein, E., Grad, Y. H., \& Lipsitch, M. (2020). Projecting the transmission dynamics of SARS-CoV-2 through the postpandemic period. Science, 368 , 860-868. doi:10.1126/science.abb5793 
Kouchaki, M., \& Gino, F. (2016). Memories of unethical actions become obfuscated over time. Proceedings of the National Academy of Sciences, 113, 6166-6171. doi:10.1073/pnas.1523586113

Kroencke, L., Geukes, K., Utesch, T., Kuper, N., \& Back, M. D. (2020). Neuroticism and emotional risk during the Covid-19 pandemic. doi: 10.31234/osf.io/8c6nh

Lahey, B. B. (2009). Public health significance of neuroticism. American Psychologist, 64, 241256. doi:10.1037/a0015309

Lakens, D., Adolfi, F. G., Albers, C., Anvari, F., Apps, M. A. J., Argamon, S. E., . . Zwaan, R. (2018). Justify your alpha. Nature Human Behaviour, 2, 168 -171. doi:10.1038/s41562018-0311-X

Larsen, M. V., Petersen, M., \& Nyrup, J. (2020). Do survey estimates of the public's compliance with COVID-19 regulations suffer from social desirability bias? doi:10.31234/osf.io/cy4hk

Leary, M. R., \& Kowalski, R. M. (1990). Impression management: A literature review and twocomponent model. Psychological Bulletin, 107, 34-47. doi:10.1037/0033-2909.107.1.34

Lewin, J. (1951). Field theory in social science. New York, NY: Harper.

Lu, J. G., Liu, X. L., Liao, H., \& Wang, L. (2020). Disentangling stereotypes from social reality: Astrological stereotypes and discrimination in China. Journal of Personality and Social Psychology. doi:10.1037/pspi0000237

Marcus, B., \& Schuler, H. (2004). Antecedents of counterproductive behavior at work: A general perspective. Journal of Applied Psychology, 89, 647-660. doi:10.1037/0021 9010.89.4.647 
Matz, S. C., Gladstone, J. J., \& Stillwell, D. (2017). In a world of big data, small effects can still matter: A reply to Boyce, Daly, Hounkpatin, and Wood (2017). Psychological Science, 28, 547-550. doi:10.1177/0956797617697445

Matz, S. C., Kosinski, M., Nave, G., \& Stillwell, D. J. (2017). Psychological targeting as an effective approach to digital mass persuasion. Proceedings of the National Academy of Sciences, 114, 12714-12719. doi:10.1073/pnas.1710966114

McCrae, R. R. (1996). Social consequences of experiential openness. Psychological Bulletin, 120, 323-337. doi:10.1037/0033-2909.120.3.323

McCrae, R. R., \& Costa, P. T. (1989). The structure of interpersonal traits: Wiggins's circumplex and the five-factor model. Journal of Personality and Social Psychology, 56, 586-595. doi: $10.1037 / 0022-3514.56 .4 .586$

McCrae, R. R., \& Costa, P. T. (2010). NEO Inventories professional manual. Lutz, FL: Psychological Assessment Resources.

McFarland, S., Webb, M., \& Brown, D. (2012). All humanity is my ingroup: A measure and studies of identification with all humanity. Journal of Personality and Social Psychology, 103(5), 830-853. doi:10.1037/a0028724

Mischel, W. (1977). The interaction of person and situation. In D. Magnusson \& N. S. Endler (Eds.), Personality at the crossroads: Current issues in interactional psychology (pp. 333-352). Hillsdale, NJ: Lawrence Erlbaum.

Muck, P. M., Hell, B, \& Gosling, S. D. (2007). Construct validation of a short Five-Factor Model instrument: A self-peer study on the German adaptation of the Ten-Item Personality Inventory (TIPI-G). European Journal of Personality Assessment, 23, 166-175. doi:10.1027/1015-5759.23.3.166 
Neil, L. (2020). How many (and whose) lives would you bet on your theory? Retrieved from: https://thehardestscience.com/2020/05/01/how-many-and-whose-lives-would-you-bet-onyour-theory/

Obschonka, M., Schmitt-Rodermund, E., Silbereisen, R. K., Gosling, S. D., \& Potter, J. (2013). The regional distribution and correlates of an entrepreneurship-prone personality profile in the United States, Germany, and the United Kingdom: A socioecological perspective. Journal of Personality and Social Psychology, 105, 104-122. doi:10.1037/a0032275

Oshio, A., Abe, S., \& Cutrone, P. (2012). Development, reliability, and validity of the japanese version of ten item personality inventory (TIPI-J). The Japanese Journal of Personality, 21, 40-52. doi:10.2132/personality.21.40

Odoxa. (2020). Lutte contre le Covid-19: Réactions de Français. Retrieved from: http://www.odoxa.fr/sondage/francais-confinement-bonne-chose-aurait-meme-etredecide-plus-tot/

Ozer, D. J., \& Benet-Martínez, V. (2006). Personality and the prediction of consequential outcomes. Annual Review of Psychology, 57, 401-421. doi:10.1146/annurev.psych .57 .102904 .190127

Painter, M., \& Qiu, T. (2020). Political beliefs affect compliance with COVID-19 social distancing orders. SSRN Electronic Journal. doi:10.2139/ssrn.3569098

Parks-Leduc, L., Feldman, G., \& Bardi, A. (2015). Personality Traits and Personal Values: A Meta-Analysis. Personality and Social Psychology Review, 19, 3-29. doi:0.1177/1088868314538548 
Paulhus, D. L., Harms, P. D., Bruce, M. N., \& Lysy, D. C. (2003). The over-claiming technique: Measuring self-enhancement independent of ability. Journal of Personality and Social Psychology, 84, 890-904. doi:10.1037/0022-3514.84.4.890

Pollet, T. V., Roberts, S. G. B., \& Dunbar, R. I. M. (2011). Extraverts have larger social network layers. Journal of Individual Differences, 32, 161-169. doi:10.1027/1614-0001/a000048

Plomin, R., DeFries, J. C., \& Loehlin, J. C. (1977). Genotype-environment interaction and correlation in the analysis of human behavior. Psychological Bulletin, 84, 309-322. doi:10.1037/0033-2909.84.2.309

Rammstedt, B., Danner, D., Soto, C. J., \& John, O. P. (2020). Validation of the short and extrashort forms of the Big Five inventory-2 (BFI-2) and their German adaptations. European Journal of Psychological Assessment, 36, 149-161. doi:10.1027/1015-5759/a000481

Rauthmann, J. F., Gallardo-Pujol, D., Guillaume, E. M., Todd, E., Nav, C. S., Sherman, R. A., Ziegler, M., Jones, A. B., \& Funder, D. C. (2014). The situational Eight DIAMONDS: A taxonomy of major dimensions of situation characteristics. Journal of Personality and Social Psychology, 107, 677-718. doi:10.1037/a0037250

Raynor, D. A., \& Levine, H. (2009). Associations between the five-factor model of personality and health behaviors among college students. Journal of American College Health, 58, 73-82. doi:10.3200/jach.58.1.73-82

Roberts, B. W., Chernyshenko, O. S., Stark, S., \& Goldberg, L. R. (2005). The structure of conscientiousness: An empirical investigation based on seven major personality questionnaires. Personnel Psychology, 58, 103-139. doi: 10.1111/j.17446570.2005.00301.x 
Roberts, B. W., Smith, J., Jackson, J. J., \& Edmonds, G. (2009). Compensatory conscientiousness and health in older couples. Psychological Science, 20, 553-559. doi: 10.1111/j.1467-9280.2009.02339.x

Roberts, B. W., Walton, K. E., \& Bogg, T. (2005). Conscientiousness and health across the life course. Review of General Psychology, 9, 156-168. doi: 10.1037/1089-2680.9.2.156

Roccas, S., Sagiv, L., Schwartz, S. H., \& Knafo, A. (2002). The big five personality factors and personal values. Personality and Social Psychology Bulletin, 28, 789-801. doi: $10.1177 / 0146167202289008$

Ross, L., \& Nisbett, R. E. (1991). The person and the situation: Perspectives of social psychology. New York, NY: McGraw-Hill.

Schaller, M., \& Murray, D. R. (2008). Pathogens, personality, and culture: Disease prevalence predicts worldwide variability in sociosexuality, extraversion, and openness to experience. Journal of Personality and Social Psychology, 95, 212-221. doi:10.1037/0022-3514.95.1.212

Schaller, M., \& Park, J. H. (2011). The behavioral immune system (and why it matters). Current Directions in Psychological Science, 20, 99-103. doi:10.1177/0963721411402596

Schoen, H., \& Steinbrecher, M. (2013). Beyond total effects: Exploring the interplay of personality and attitudes in affecting turnout in the 2009 German federal election. Political Psychology, 34, 533-552. doi:10.1111/pops.12031

Shaffer, J. P. (1995). Multiple hypothesis testing. Annual Review of Psychology, 46, 561-584. doi: 10.1146/annurev.ps.46.020195.003021 
Soto, C. J. (2019). How replicable are links between personality traits and consequential life outcomes? The life outcomes of personality replication project. Psychological Science, 30, 711-727. doi:10.1177/0956797619831612

Soto, C. J., \& John, O. P. (2017). The next Big Five Inventory (BFI-2): Developing and assessing a hierarchical model with 15 facets to enhance bandwidth, fidelity, and predictive power. Journal of Personality and Social Psychology, 113, 117-143. doi:10.1037/pspp0000096

Strickhouser, J. E., Zell, E., \& Krizan, Z. (2017). Does personality predict health and well-being? A metasynthesis. Health Psychology, 36, 797-810. doi:10.1037/hea0000475

Sutin, A. R., Stephan, Y., Luchetti, M., Artese, A., Oshio, A., \& Terracciano, A. (2016). The five-factor model of personality and physical inactivity: A meta-analysis of 16 samples. Journal of Research in Personality, 63, 22-28. doi: 10.1016/j.jrp.2016.05.001

Tankard, M. E., \& Paluck, E. L. (2017). The effect of a supreme court decision regarding gay marriage on social norms and personal attitudes. Psychological Science, 28, 1334-1344. doi:10.1177/0956797617709594

Tett, R. P., \& Burnett, D. D. (2003). A personality trait-based interactionist model of job performance. Journal of Applied Psychology, 88, 500-517. doi: 10.1037/00219010.88 .3 .500

Tett, R. P., \& Guterman, H. A. (2000). Situation trait relevance, trait expression, and crosssituational consistency: Testing a principle of trait activation. Journal of Research in Personality, 34, 397-423. https://doi.org/10.1006/jrpe.2000.2292 
Trobst, K. K., Wiggins, J. S., Costa, Jr., P. T., Herbst, J. H., McCrae, R. R., \& Masters, III, H. L. (2000). Personality psychology and problem behaviors: HIV risk and the five-factor model. Journal of Personality, 68, 1233-1252. doi:10.1111/1467-6494.00133

Tybur, J. M., Inbar, Y., Aarøe, L., Barclay, P., Barlow, F. K., de Barra, M., ... Žeželj, I. (2016). Parasite stress and pathogen avoidance relate to distinct dimensions of political ideology across 30 nations. Proceedings of the National Academy of Sciences, 113, 12408-12413. doi:10.1073/pnas.1607398113

van Bavel, J. J., Baicker, K., Boggio, P. S., Capraro, V., Cichocka, A., Cikara, M., ... Willer, R. (2020). Using social and behavioural science to support COVID-19 pandemic response. Nature Human Behaviour, 4, 460-471. doi:10.1038/s41562-020-0884-z

van Holm, E. J., Monaghan, J., Shahar, D. C., Messina, J., \& Surprenant, C. (2020). The impact of political ideology on concern and behavior during COVID-19. SSRN Electronic Journal. doi:10.2139/ssrn.3573224

Wilson, R. E., Harris, K., \& Vazire, S. (2015). Personality and friendship satisfaction in daily life: Do everyday social interactions account for individual differences in friendship satisfaction? European Journal of Personality, 29, 173-186. doi: 10.1002/per.1996 Wu, Z., \& McGoogan, J. M. (2020). Characteristics of and important lessons from the Coronavirus Disease 2019 (COVID-19) outbreak in China: Summary of a report of 72314 cases from the chinese center for disease control and prevention. JAMA - Journal of the American Medical Association, 323, 1239-1242. doi:10.1001/jama.2020.2648 